Postgraduate Bosowa University Publishing (PBUP)
Indonesian Journal of Business and Management
e-ISSN: $2460-3767 \quad p$-ISSN: $2656-6885$
inttps://postgraduate.universitasbosowan
JOURAL

\title{
HUBUNGAN PENGARUH PENERAPAN PRINSIP GOOD GOVERNANCE TERHADAP KINERJA PELAYANAN PENERBITAN SURAT KETERANGAN UJI KETERAMPILAN PENGEMUDI (SKUKP) PADA DIREKTORAT LALU LINTAS POLDA SULAWESI SELATAN
}

\author{
Effects of The Implementation oOf Good Governance Principles on The Performance of Issuing Driver Skills Test \\ Certificate (SKUKP) Ditlantas Polda South Sulawesi
}

\author{
Lharasati Pratiwi ${ }^{1}$, Hasanuddin Remmang ${ }^{2}$, Herminawaty Abubakar ${ }^{2}$ \\ ${ }^{1}$ Kepolisian Daerah Provinsi Sulawesi Selatan \\ ${ }^{2}$ Program Studi Manajemen Program Pascasarjana Universitas Bosowa
}

Email: lharasatiprwatiwi@gmail.com

Diterima: 20 September 2021/Disetujui: 24 Desember 2021

\begin{abstract}
ABSTRAK
Tujuan penelitian ini adalah: (1) untuk mengetahui dan menganalisis penerapan prinsip-prinsip good governance dengan variabel akuntabilitas, transparansi, partisipasi, efektivitas dan efisiensi serta kepastian hukum memiliki pengaruh terhadap kinerja variabel dalam Ditlantas Polda Sulawesi Selatan dan (2) untuk mengetahui dan menganalisis tentang prinsip-prinsip Good Governance yang paling berpengaruh terhadap kinerja Penerbitan Surat Keterangan Tes Keterampilan Pengemudi (SKUKP) Ditlantas Polda Sulawesi Selatan. Penelitian ini dilakukan di Subdirektorat Kependudukan Ditlantas Polda Sulawesi Selatan dengan jumlah populasi 133 responden (metode sensus). Analisis data yang digunakan adalah deskriptif untuk menjelaskan gambaran responden dan deskripsi penelitian, sedangkan untuk menganalisis data kuantitatif menggunakan analisis Regresi Berganda. Penelitian ini mengkaji tentang prinsip-prinsip good governance yang berpengaruh terhadap kinerja personel Polri di Subdit Ditlantas Polda Sulawesi Selatan. Hasil penelitian menunjukkan bahwa nilai rata-rata R, R2 memberikan pengaruh yang signifikan. Korelasi regresi untuk variabel akuntabilitas (X1), transparansi (X2), partisipasi (X3), efektivitas dan efisiensi (X4) dan kepastian hukum (X5) serta konstanta koefisien regresi juga berpengaruh signifikan. Dan variabel akuntabilitas dominan (X1) berpengaruh terhadap kinerja pegawai, setelah dilakukan pengujian dengan uji $\mathrm{F}$ dan uji t yang menunjukkan pengaruh yang signifikan.
\end{abstract}

Kata Kunci: Akuntabilitas, Transparansi, Partisipasi, Efektif dan Efisien, Kepastian Hukum dan Kinerja

\section{ABSTRACT}

The purposes of this study are: (1) to determine and analyze the application of the principles of good governance with the variables of accountability, transparency, participation, effectiveness and efficiency as well as legal certainty have an influence on the performance of variables in the Ditlantas Polda South Sulawesi and (2) to find out and analyze about the principles of Good Governance that most influence the performance of the Issuance of Certificate of Driver Skill Test (SKUKP) Ditlantas Polda South Sulawesi. This research was conducted at the Regident Sub-Directorate of Ditlantas Polda South Sulawesi with a total population of 133 respondents (census method). Analysis of the data used is descriptive to explain the respondent's description and description of the research, while to analyze quantitative data using Multiple Regression analysis. This study examines the principles of good governance that affect the performance of Polri personnel in the Regident Sub-Directorate of the Ditlantas Polda South Sulawesi. The results showed that the average value of R, R2 gave a significant effect. Regression correlations for the variables of accountability (X1), transparency (X2), participation (X3), effectiveness and efficiency (X4) and legal certainty (X5) as well as regression coefficient constants also have a significant effect. And the dominant accountability variable (X1) has an effect on personnel performance, after testing with the F-test and t-test which shows a significant effect.

Keywords: Accountability, Transparency, Participation, Effective and Efficient, Legal Certainty and Performance 


\section{PENDAHULUAN}

Kepolisian Negara Republik Indonesia merupakan alat Negara yang berperan dalam memelihara keamanan dan ketertiban masyarakat, menegakkan hukum, memberikan pengayoman dan pelayanan kepada masyarakat. Dalam menjalankan perannya, Polri wajib memiliki keahlian dan keterampilan secara profesional, Jamil (2001). Undang-Undang Nomor 2 Tahun 2002 tentang Kepolisian Negara Republik Indonesia, ini telah didasarkan kepada paradigma baru sehingga diharapkan dapat lebih memantapkan kedudukan dan peranan serta pelaksanaan tugas Kepolisian Negara Republik Indonesia sebagai bagian integral dari reformasi menyeluruh segenap tatanan kehidupan bangsa dan negara dalam mewujudkan masyarakat madani yang adil, makmur, dan beradab berdasarkan Pancasila dan Undang-Undang Dasar Negara Republik Indonesia Tahun 1945.

Direktorat Lalu Lintas adalah organisasi dibawah Kepolisian Negara Republik Indonesi yang bertugas membina dan, dalam batas kewenangan yang ditentukan, menyelenggarakan fungsi lalu lintas yang meliputi kegiatan pendidikan masyarakat, penegakan hukum, pengkajian masalah lalu lintas, registrasi dan identifikasi pengemudi dan kendaraan bermotor serta patrol jalan raya yang bersifat antar wilayah hukum Negara Republik Indonesia. Melakukan koordinasi pelaksanaan tugas dengan Badan atau Instansi Pemerintah yang terkait dengan lalu lintas kendaraan dan jalan raya. Direktorat Lalu Lintas juga merupakan bagian kerja dari kepolisian berperan dalam memberikan keselamatan kepada pengguna jalan raya. Untuk itu dalam rangka pemberdayaan dan pengembangan industri di bidang lalu lintas dan angkutan jalan, dalam Undang-Undang Nomor: 22 tahun 2009 ditegaskan bahwa Pemerintah berkewajiban mendorong industri dalam negeri, antara lain dengan cara memberikan fasilitas, insentif, dan menerapkan standar produk peralatan Lalu Lintas dan Angkutan Jalan.

Pelaksanaan good governance di lingkungan Direktorat Lalu Lintas Polda Sulsel mencakup Konsentrasi Ditlantas dalam menjalankan organisasinya dalam mencapai sasaran dari visi dan misinya. Sesuai dengan prinsip-prinsip keterbukaan, keadilan serta dapat dipertanggungjawabkan. Selain itu juga mencakup pelaksanaan interaksi Direktorat Lalu Lintas Polda Sulsel dengan masyarakat agar dapat berjalan dengan baik tanpa mengabaikan tujuan organisasi yang harus dicapai.

Tujuan utama dari implementasi prinsip-prinsip good governance yaitu kinerja organisasi semakin meningkat serta hak dan kewajiban masyarakat dapat terpenuhi (Nubatonis dkk., 2014). Dari perspektif agency theory, pengukuran kinerja yang baik akan mengurangi asimetri informasi dan dapat mencegah manajer publik untuk berperilaku oportunis (dysfunctional behavior), yang selanjutnya akan dapat terwujud tata kelola pemerintahan yang baik (Ulum, 2011). Dalam penelitian ini, principal adalah Kepolisian Republik Indonesia
(Kapolri) dan agen adalah Direktorat Lalu Lintas. Oleh karena itu, governance merupakan suatu sistem yang sangat penting untuk diimplementasikan guna menyelaraskan kepentingan antara kedua belah pihak (Kapolri dan Direktorat Lalu Lintas).

Dewasa ini, struktur kelembagaan pemerintah belum memberikan indikasi terciptanya kondisi yang kondusif dalam mengantisipasi aspirasi dan tuntutan kebutuhan masyarakat dengan dinamika perkembangan yang begitu cepat. Aparat pada level terdepan yang bersifat operasional sebagai ujung tombak untuk menunjukkan kinerja yang baik belum terwujud. Selama ini aparat lebih banyak diarahkan untuk pengisian dan pemenuhan aspek struktural dan bersifat manajerial serta prestisi bagi seorang aparat. Fenomena ini mengakibatkan aspek kinerja yang baik sulit direalisasikan dan bahkan telah menjadi budaya ingin dilayani di kalangan birokrat.

Good Governance (kepemerintahan yang baik) merupakan issue yang paling menarik dalam pengelolaan administrasi publik dewasaini. Kondisi kepemerintahan ini merupakan tuntut angencar yang dilakukan oleh masyarakat kepada pemerintah untuk menyelenggarakan pemerintahan yang baik. Hal ini sejalan dengan meningkatnya tingkat pengetahuan masyarakat, disamping adanya pengaruh globalisasi. Penempatan sistem penyelenggaraan kepemerintahan yang baik memungkinkan untuk terlaksananya pembangunan yang berlangsung secara berdayaguna, berhasil guna, bersih dan bertanggung jawab, serta bebas dari korupsi, kolusi dan nepotisme $(\mathrm{KKN})$.

Terciptanya Good Governance akan diikuti pula dengan Clean Government yaitu pemerintahan yang bersih dan berwibawa, artinya sistem pemerintahan yang mampu melindungi masyarakatnya dengan prinsip penegak hukum yang dipatuhi oleh semua lapisan masyarakat. Dengan kondisi tersebut pada akhirnya akan menjadikan pemerintahan yang kuat (Strong Governance) dalam arti semakin kuatnya penyelenggaraan pemerintahan lainya.

Dalam mengimplementasikan good governance, ada beberapa faktor yang menjadi pusat perhatian diantaranya adalah; 1) akuntabilitas, 2) transparansi, 3) partisipasi, 4) efektivitas dan efisiensi, dan 5) kepastian hukum. Kelima faktor tersebut merupakan kenyataan yang harus diakomodasi oleh pimpinan Polri Direktorat Lalu Lintas Polda Sulawesi Selatan, yang Tertuma pada Subdit Regident. Good Governance harus menjadi prioritas dalam pembangun dan mengupayakan berbagai usaha untuk mencari alternative yang tepat, agar good governance dapat ditingkatkan pada semua aktivitas Personil Polri Subdit Regident Ditlantas.

Fenomena yang terjadi di lingkungan Subdit Regident Ditlantas Polda Sulawesi Selatan bahwa kinerja personil polri untuk dewasa ini masih banyak dijumpai kelemahan sehingga belum dapat memenuhi kualitas yang diharapkan masyarakat. Hal ini ditandai dengan masih 
adanya berbagai keluhan masyarakat yang disampaikan baik melalui media maupun secara langsung, sehingga dapat menimbulkan citra yang kurang baik terhadap Subdit Regidet Ditlantas Polda Sulawesi Selatan. Tujuan penelitian ini untuk mengetahui pengaruh penerapan prinsip good governance terhadap kinerja pelayanan penerbitan surat keterangan uji keterampilan pengemudi (SKUKP) Pada Direktorat Lalu Lintas Polda Sulawesi Selatan.

\section{METODE}

a. Jenis Penelitian

Penelitian ini bertujuan untuk menghasilkan deskripsi dan analisis bagaimana perilaku, tindakan, dan peranan Penerbitan Surat Keterangan Uji Keterampilan Pengemudi (SKUKP) Pada Direktorat Lalu Lintas Polda Sulawesi Selatan dalam penerapan prinsip-prinsip good governance dalam pelayanan dan keterbukaan informasi publik berdasarkan Undang-Undang Republik Indonesia Nomor 2 Tahun 2002 tentang Kepolisian Negara Republik Indonesia.

Peneliti menggunakan tipe penelitian kuantitatif ini karena sesuai dengan kebutuhan penelitian dalam melihat dan memaparkan terkait gejala-gejala yang terdapat di dalam masalah penelitian yaitu mendeskripsikan dan menganalisis kejadian empiris mengenai bagaimana pengaruh penerapan prinsip good governance oleh Penerbitan Surat Keterangan Uji Keterampilan Pengemudi (SKUKP) Ditlantas Polda Sulawesi Selatan.

\section{b. Populasi dan Sampel}

Dalam penelitian ini yang dijadikan Informan ditentukan secara Purposive Sampling, dimana pemilihan informan dilihat berdasarkan ketentuan bahwa informan tersebut adalah yang melakukan, mengetahui dan memahami dengan persis masalah yang dikaji. Untuk memperoleh data dalam penelitian ini maka yang menjadi sampel adalah keseluruhan personil Polri Penerbitan Surat Keterangan Uji Keterampilan Pengemudi (SKUKP) Ditlantas Polda Sulawesi Selatan yang berjumlah 199 orang.

\section{c. Teknik Pengumpulan Data}

1) Observasi, dilakukan untuk mendapatkan gambaran terhadap permasalahan yang diteliti dengan cara melakukan pengamatan obyek secara langsung selama pengumpulan data. Melalui metode ini, realitas dan konteks penelitian dapat dipahami secara mendalam. Obyek-obyek yang diobservasi terdiri dari kondisi lingkungan dari aktivitas sosial dan aktivitas lainya.

2) Wawancara, yang dilakukan dalam penelitian ini adalah wawancara mendalam dan wawancara berpedoman (terikat). Pengumpulan data dengan wawancara perpedoman didasarkan pada daftar pertanyaan yang telah disiapkan. Sedangkan wawancara bebas dan mendalam adalah pertanyaan pengembangan dari pertanyaan terikat yang tidak disiapkan sebelumnya baik kepada Personil Subdit Regident Ditlantas Polda Sulawesi Selatan.

3) Kuesioner, Adalah teknik pengumpulan data dengan mengajukan sejumlah pertanyaan secara tertulis yang diberikan kepada responden dengan maksud untuk memperoleh data yang akurat dan valid.

4) Dokumentasi, Adapun pengumpulan data dengan melihat dan mempelajari dokumen- dokumen tertulis mengenai keadaan lokasi penelitian. Studi tersebut dilakukan baik di lokasi penelitian maupun di tempat-tempat lain dimana data tentang objek yang diteliti dapat diperoleh.

\section{d. Teknis Analisis Data}

Berdasarkan rumusan permasalahan, hipotesis dan kerangka konseptual yang telah dikemukakan pada bagian terdahulu, maka akan dilakukan analisa secara kuantitatif dengan menggunakan metode Regresi linear berganda dengan rumus sebagai berikut :

$$
\begin{aligned}
& \mathrm{Y}=\mathrm{B} 0+\mathrm{B} 1 \mathrm{X} 1+\mathrm{B} 2 \mathrm{X} 2+\mathrm{B} 3 \mathrm{X} 3+\mathrm{B} 4 \mathrm{X} 4+\mathrm{B} 5 \mathrm{X} 5+\mathrm{ei} \\
& \mathrm{Y}=\text { Kinerja Personil Klipeng } \\
& \mathrm{X} 1=\text { Akuntabilitas } \\
& \mathrm{X} 2=\text { Transparansi } \\
& \mathrm{X} 3=\text { Partisipasi } \\
& \mathrm{X} 4 \quad=\text { Efektif dan Efisien } \\
& \text { X5 = Kepastian hukum } \\
& \text { B1-B5 = Koefisien Regresi yang akan diestimasi } \\
& \mathrm{B} 0=\text { Konstanta } \\
& \text { ei }=\text { Faktor Kesalahan }
\end{aligned}
$$$$
\text { Dimana : }
$$

\section{HASIL DAN PEMBAHASAN}

Berdasarkan hasil penelitian menunjukkan bahwa semua variabel bebas yang telah diteliti yang mencakup Akuntabilitas, Transparansi, Partisipasi, Efektivitas \& Efisiensi, dan Kepastian Hukum secara bersama-sama (keseluruhan) berpengaruh positif dan signifikan terhadap Kinerja Personil Polri di Penerbitan Surat Keterangan Uji Keterampilan Pengemudi (SKUKP) Ditlantas Polda Sulawesi Selatan, dan secara parsial seluruh variabel bebas berpengaruh positif dan signifikan terhadap Kinerja Personil Polri di Penerbitan Surat Keterangan Uji Keterampilan Pengemudi (SKUKP) Ditlantas Polda Sulawesi Selatan. Pembahasan dari masing-masing variabel yang berpengaruh terhadap kinerja personil dapat dikemukakan sebagai berikut :

\section{1) Deskripsi Variabel Penelitian}

Dalam penelitian ini ada lima variable bebas yang dianggap berpengaruh terhadap kinerja didalam lingkup Penerbitan Surat Keterangan Uji Keterampilan Pengemudi (SKUKP) Ditlantas Polda Sulawesi Selatan. Kelima variable bebas tersebut, terdiri atas akuntabilitas, transparansi, partipasi, efektif/efisien dan kepastian hukum. Variable-variabel tersebut akan diuraikan secara deskriptif dengan mengacu pada data hasil penelitian lapangan dalam bentuk distribusi frekuensi.

a) Prinsip Akuntabilitas 
Akuntabilitas merupakan kewajiban bagi aparatur pemerintah untuk mempertanggung jawabkan segala tindakan yang telah ditetapkan. Penerapan prinsip akuntabilitas dalam pelaksanaan tugas Personel Penerbitan Surat Keterangan Uji Keterampilan Pengemudi (SKUKP) Ditlantas Polda Sulawesi Selatan sangat setuju atau $0 \%$, dan 94 orang responden memberikan pernyataan setuju atau $71 \%$, kemudian 32 orang responden atau sekitar $24 \%$ yang menyatakan cukup setuju, dan yang menyatakan tidak setuju 2 Orang atau $1 \%$, sedangkan sangat tidak setuju ditemukan dalam data penelitian ini 5 orang atau $4 \%$. Maka dapat dikatakan bahwa secara umum penerapan prinsip akuntabilitas yang dilaksanakan oleh Penerbitan Surat Keterangan Uji Keterampilan Pengemudi (SKUKP) Ditlantas Polda Sulawesi Selatan sangat baik.

b) PrinsipTransparansi

Transparansi artinya segala tindakan dan kewajiban pimpinan harus dilaksanakan secara terbuka dan diketahui umum. penerapan prinsip transparansi dalam pelaksanaan tugas personel Penerbitan Surat Keterangan Uji Keterampilan Pengemudi (SKUKP) Ditlantas Polda Sulawesi Selatan sangat baik atau 0\%. Dan 94 orang responden memberikan pernyataan baik atau $71 \%$ Kemudian 32 Orang responden atau sekitar $24 \%$ yang menyatakan cukup baik, dan yang menyatakan kurang bagus 2 responden atau $1 \%$, dan tidak bagus 5 responden atau $4 \%$ ditemukan dalam data penelitian. Maka dapat dikatakan bahwa secara umum penerapan prinsip transparansi yang dilaksanakan oleh personel Penerbitan Surat Keterangan Uji Keterampilan Pengemudi (SKUKP) Ditlantas Polda Sulawesi Selatan baik.

c) Prinsip Partisipasi

Partisipasi artinyatan pimpinan memberikan kesempatan yang luas kepada staf dalam berperan dan menghasilkan produk dan jasa. Penerapan prinsip partisipasi dalam pelaksanaan tugas Personel Penerbitan Surat Keterangan Uji Keterampilan Pengemudi (SKUKP) Ditlantas Polda Sulawesi Selatan sangat baik, atau 0\%. Dan 75 orang responden atau sekitar $57 \%$ yang menyatakan baik, dan 51 responden atau 38\% menyatakan cukup baik, dan yang menyatakan kurang baik adalah 2 responden atau $1 \%$, sementara yang menyatakan sangat kurang baik yang ditemukan dalam penelitian ini adalah 5 responden atau 4\%. Maka dapat dikatakan bahwa secara umum penerapan prinsip partisipasi yang dilaksanakan oleh Personel Penerbitan Surat Keterangan Uji Keterampilan Pengemudi (SKUKP) Ditlantas Polda Sulawesi Selatan baik.

d) Prinsip Efektivitas \& Efisiensi
Efektif dan Efisien artinya proses kegiatan diarahkan untuk menghasilkan produk / jasa sesuai dengan kebutuhan melalui pemanfaatan sumber daya yang tersedia. Penerapan prinsip efektif dan efisien dalam pelaksanaan tugas pokok personel Penerbitan Surat Keterangan Uji Keterampilan Pengemudi (SKUKP) Ditlantas Polda Sulawesi Selatan sangat setuju atau 0\% dan 90 orang responden memberikan pernyataan setuju atau $68 \%$ kemudian 36 orang responden atau $27 \%$ yang menyatakan cukup setuju, 2 orang responden yang menyatakan tidak setuju atau $1 \%$. Dan ditemukan pernyataan yang sangat tidak setuju 5 responden atau $4 \%$. Maka dapat dikatakan bahwa secara umum penerapan prinsip efektif dan efisien yang dilaksanakan oleh Personel Penerbitan Surat Keterangan Uji Keterampilan Pengemudi (SKUKP) Ditlantas Polda Sulawesi Selatan baik.

e) Kepastian Hukum

Kepastian hukum artinya penghargaan terhadap hakhak azasi manusia dan penegakan rasa keadilan dalam pelayanan. penerapan prinsip kepastian hukum dalam pelaksanaan tugas pokok personel Penerbitan Surat Keterangan Uji Keterampilan Pengemudi (SKUKP) Ditlantas Polda Sulawesi Selatan sangat bagus atau 75. Dan 27 orang responden memberikan pernyataan bagus atau 20 kemudian 2 orang responden atau sekitar 4 yang menyatakan sedang, dan yang menyatakan kurang sebanyak 5 orang atau 4 dan tidakbagus tidak ditemukan dalam data penelitian ini. maka dapat dikatakan bahwa secara umum penerapan prinsip kepastian hukum yang dilaksanakan oleh personel Penerbitan Surat Keterangan Uji Keterampilan Pengemudi (SKUKP) Ditlantas Polda Sulawesi Selatan bagus.

\section{2) Pengaruh Akuntabilitas (X1) Terhadap Kinerja Personil}

Dalam penelitian ini ada empat indkator akuntabilitas yang telah diteliti yakni penyusunan program, komitmen, keuletan dan pelaksanaan pertanggungjawaban hasil kinerja personel. Ternyata dari hasil penelitian menunjukan bahwa secara umum personel yang ada pada Penerbitan Surat Keterangan Uji Keterampilan Pengemudi (SKUKP) Ditlantas Polda Sulawesi Selatan menerapkan prinsip akuntabilitas dalam hal penyusunan program kinerja, komitmen terhadap pencapaian tujuan organisasi, keuletan dalam hal menyajikan pelayanan dan pelaksanaan pertanggungjawaban hasil kerja. Dari hasil analisis statistik juga telah menunjukan bahwa variable akuntabilitas telah menunjukan pengaruh yang signifikan terhadap kinerja personel yang ada padaKlipeng Penerbitan Surat Keterangan Uji Keterampilan Pengemudi (SKUKP) Ditlantas Polda Sulawesi Selatan. 
Hal ini akan dibuktikan dengan data kuantitatif sesuai dengan hasil temuan melalui nilali konstribusi $(\mathrm{B} 1)=$ 0,204 atau 20,4\% dan juga dapat diperlihatkan melalui hasil signifikansinya yaitu thitung $=2,970$ dengan $\mathrm{p}=$ $0,004<0,05$.

Dari indikator akuntabilitas yang dikemukan di atas, berdasarkan data statistik melalui frequensi table pada lampiran 17, terdapat 94 atau $70,7 \%$ responden yang mengungkapkan bahwa sangat setuju terhadap penerapan akutabilitas terhadap kinerja pada Penerbitan Surat Keterangan Uji Keterampilan Pengemudi (SKUKP) Ditlantas Polda Sulawesi Selatan. Konsep akuntabilitas pada Penerbitan Surat Keterangan Uji Keterampilan Pengemudi (SKUKP) Ditlantas Polda Sulawesi Selatan didasarkan pada klasifikasi responsibilitas managerial pada tiap tingkatan dalam organisasi yang bertujuan untuk pelaksanaan kegiatan pada tiap bagian masing - masing individu.

Dengan demikian para Personil Penerbitan Surat Keterangan Uji Keterampilan Pengemudi (SKUKP) Ditlantas Polda Sulawesi Selatan perlu terus untuk meningkatkan implementasi akuntabilitas yang mencakup keseluruhan aspek tingkah laku seorang personil yang bersifat pribadi yang disebut akuntabilitas pribadi, maupun prilaku bersifat Kolektif (hubungan antara sesame personil dan terhadap organisasi). Penegasan ini sejalan dengan pendapat yang dikemukakan oleh Nordiawan dan Hertianti (2010) dalam rangka mewujudkan good governance dimana akuntabilitas menjadi salah satu prinsip yang harus dikedepankan dalam penyelenggaraan pemerintahan.

\section{3) Pengaruh Transparansi (X2) Terhadap Kinerja Personil}

Hasil penelitian ini menunjukkan bahwa penerapan prinsip transparansi pada Personil Klipeng Penerbitan Surat Keterangan Uji Keterampilan Pengemudi (SKUKP) Ditlantas Polda Sulawesi Selatan telah menunjukkan kondisi yang baik dan berpengaruh signifikan terhadap kinerja yang dilakukan oleh Personil Klipeng Penerbitan Surat Keterangan Uji Keterampilan Pengemudi (SKUKP) Ditlantas Polda Sulawesi Selatan. Sehingga implementasi prinsip ini terus ditingkatkan dimasa yang akan datang, minimal mempertahankan kondisi yang ada sekarang.hal ini akan dibuktikan melalui data statistik melalui nilali konstribusi $\left(\mathrm{B}_{2}\right)=0,304$ atau $30,4 \%$ dan juga dapat diperlihatkan melalui hasil signifikansinya yaitu $t_{\text {hitung }}=$ 3,622 dengan $\mathrm{p}=0,000<0,05$.

Penjelasan di atas mendukung hasil penelitian yang dilakukan oleh Aniza Nur Madyanti (2005) yang berjudul "Analisis Pengaruh Praktek Good Governance Terhadap Kualitas Pelayanan Kemahasiswaan di Akademi Pimpinan Perusahaan". Berdasarkan hasil analisis deskriktif, dan analisis korelasi dengan pendekatan pada teori good governance dan kualitas pelayanan yang telah dikemukakan sebelumnya, maka dapat disimpulkan bahwa terdapat pengaruh yang positif antara praktek good governance dengan kualitas pelayanan. Pengaruh yang paling dominan dengan good governance terhadap kualitas pelayanan kemahasiswaan adalah transparansi. Kontribusi praktek good governance mempengaruhi kualitas pelayanan kemahasiswaan sebesar 64,48\%. Ini berarti bahwa salah satu faktor yang mempengaruhi kualitas pelayanan kemahasiswaan, praktek good governance memberikan sumbangan $64,48 \%$ dalam kenaikanya. Sisanya, yaitu $35,52 \%$ berasal dari faktorfaktor yang lain, seperti SDM yang berkualitas dan berkompeten, sistem dan prosedur, sumber daya keuangan dan lainya.

Oleh karena itu untuk mendukung transparansi maka personil Polri telah melakukan sosialisasi. Karena prinsip dari transparansi adalah melaksanakan keterbukaan dalam setiap kegiatan yang dilakukan oleh Penerbitan Surat Keterangan Uji Keterampilan Pengemudi (SKUKP) Ditlantas Polda Sulawesi Selatan atas kewenangan yang dimilikinya. Prinsip tersebut berkaitan erat dengan keterbukaan terhadap efektivitas kegiatan dalam pencapaian sasaran kebijakan ataupun program yang telah ditetapkan.

Penegasan ini sejalan dengan pendapat yang dikemukakan oleh Haris (2006), semua program dan kebijaksanaan yang dibuat oleh para pejabat pemerintah harus dibuat secara transparan (jelas) kepada masyarakat agar supaya masyarakat memiliki akses untukikut serta secara aktif berpartisipasi baik secara langsung maupun melalui lembaga perwakilan dalam melakukan kontrol terhadap kinerja birokrasi pemerintah (control of government by the governed).

\section{4) Pengaruh Partisipasi (X3) Terhadap Kinerja Personil}

Dalam hasil penelitian ini menunjukkan bahwa secara umum tingkat partisipasi personel Klipeng Penerbitan Surat Keterangan Uji Keterampilan Pengemudi (SKUKP) Ditlantas Polda Sulawesi Selatan dalam menjalankan tugas pokok dan fungsinya sudah baik. Hasil penelitian ini menunjukkan pula bahwa variabel partisipasi berpengaruh signifikan terhadap kinerja Personil Polri di Klipeng Penerbitan Surat Keterangan Uji Keterampilan Pengemudi (SKUKP) Ditlantas Polda Sulawesi Selatan yang dibutikan melalui uji statistic data statistik melalui nilali konstribusi $(\mathrm{B} 3)=$ 0,143 atau 14,3\% dan juga dapat diperlihatkan melalui hasil signifikansinya yaitu thitung $=2,199$ dengan $\mathrm{p}=$ $0,030<0,05$.

Pengaruh positif yang dibuktikan melalui data statistik sebagai bukti bahwa pada Penerbitan Surat Keterangan Uji Keterampilan Pengemudi (SKUKP) Ditlantas Polda Sulawesi Selatan sangat dituntut agar setiap personil Polri harus aktif untuk berpartisipasi dengan masyarakat sebagai stakeholders. Sehingga masyarakat mendapatkan kesempatan yang luas dalam menghasilkan pelayanan publik yang efektif.

Selain itu, peningkatan partisipasi dapat juga dilakukan melalui pemberdayaan personel. Pemberdayaan disini dimaksud menempatkan personel sebagai subjek 
dari organisasi. Karena itu, dalam pemberdayaan personel menekankan pada proses menstimulas, mendorong dan memotivasi individu agar mempunyai kemampuaan atau keberdayaan, (Sudarmayanti, 2004).

Sejalan dengan perlu peningkatan partisipasi personel. Oleh Indrianty mengemukakan (2006) para pejabat harus mampu membuat semua aparatnya tarlibat (berpartisipasi) dalam upaya penyajian pelayanan prima yang mampu memuaskan publik. Proses tersebut meliputi pelayanan kepada publik sebagai pelanggang eksternal maupun bagi sesama aparat sebagai pelanggang internal.

\section{5) Pengaruh Efektivitas dan Efisiensi (X4) Terhadap Kinerja Personil}

Dari hasil penelitian menunjukan bahwa Personil Polri di Penerbitan Surat Keterangan Uji Keterampilan Pengemudi (SKUKP) Ditlantas Polda Sulawesi Selatan telah menerapkan prinsip efektif dan efesien dengan baik dalam menyelesaikan tugas pokok dan fungsinya kearah pencapaian tujuan dan sasaran organisasi pemerintah.

Hasil penelitian ini menunjukan pula adanya pengaruh yang signifikan implementasi prinsip efektif dan efesien terhadap kinerja Personil Polri di Direktorat Lalu Lintas Polda Sulawesi Selatan yang dibutikan melalui uji statistic data statistik melalui nilali konstribusi (B4) $=0,, 193$ atau 19,3\% dan juga dapat diperlihatkan melalui hasil signifikansinya yaitu thitung $=2,582$ dengan $\mathrm{p}=0,011<0,05$.

Dapat pula dijelaskan bahwa Personil Polri di Penerbitan Surat Keterangan Uji Keterampilan Pengemudi (SKUKP) Ditlantas Polda Sulawesi Selatan telah dituntut untuk tidak hanya mampu membuat perencanaan yang baik, profesional, melainkan telah mampu untuk menghasilkan hasil yang efektif dan efesien pada tingkat operasional dengan kulaitas sumber daya yang dimiliki. Disadari bahwa prinsip efektif dan efisien menghendaki bahwa setiap proses kegiatan dan kelembagaan diarahakan untuk menghasilkan sesuatu yang benar - benar sesuai dengan kebutuhan.

Dengan demikian, diharapkan supaya pimpinan pada instansi ini dapat terus meningkatkan efesiensi dalam penggunaan sumber daya organisasi yang ada dan masyarakat yang membutuhkan kinerja dari organisasi tersebut.

\section{6) Pengaruh Kepastian Hukum (X5) Terhadap Kinerja Personil}

Kepastian hukum yang disoroti dalam penelitian ini, mencakup empat indikator yakni: tidak ada perbedaan dalam pelayanan, penghargaan hak-hak asasi manusia, konsistensi terhadap prosedur kerja dan kepastian hukum hasil inerja. Hasil penelitian ini menunjukkan pula adanya pengaruh signifikan kepastian hukum terhadap kinerja Personil Polri di Penerbitan Surat Keterangan Uji Keterampilan Pengemudi (SKUKP) Ditlantas Polda Sulawesi Selatan, hal tersebut dibutikan melalui uji statistic data statistik melalui nilali konstribusi $($ B5) $=$ 0,187 atau $18,7 \%$ dan juga dapat diperlihatkan melalui hasil signifikansinya yaitu thitung $=2,286$ dengan $\mathrm{p}=$ $0,024<0,05$. Dengan demikian diharapkan supaya pimpinan pada instansi ini dapat terus meningkatkan adanya kepastian hukum dalam memberikan pelayanan kepada masyarakat.

Konsep dari teori yang mendukung perlu penegakan hukum dikemukakan oleh UNDP yang diuraikan oleh Sedarmayanti (2004:7) tegaknya hukum yang berkeadilan mutlak diperlukan dalam penyelenggaraan pemerintahan dan pembangunan. Adanya kepastian hukum merupakan indikator profesionalisme dan syarat bagi kredibilitas pemerintah. Tegaknya kepastian hukum juga mensyaratkan kecermatan dalam penyusunan berbagai kebijakan pembangunan.

\section{KESIMPULAN DAN SARAN}

Hasil penelitian dapat disimpulkan bahwa faktor yang paling dominan berpengaruh terhadap kinerja Personil Polri di Penerbitan Surat Keterangan Uji Keterampilan Pengemudi (SKUKP) Ditlantas Polda Sulawesi Selatan adalah Transparansi. Informasi

\section{DAFTAR PUSTAKA}

Abdul Samad, 2003. Analisis Faktor - faktor Kemampuan Kerja yang Berpengaruh Terhadap Peningkatan Kinerja pada Dinas Pendidikan dan Kebudayaan PropinsiSulawesi Selatan. Tesis Program Pascasarjana Universitas Muslim Indonesia, Makassar.

B.Arif Sidharta, 2000, Terjemahan Jan Gijssels dan Mark Van Hoecke Tentang Apakah teori Hukum Itu, Bandung.

Bhatta, Gambir, 1996. Capacity Building at the Local Level For Effective Governance, Empowerment Without Capacity is Meaningless.

Dwidjowijot, Riant Nugroho 2003, Kebijakan Publik, Pormulasi, ImplementasidanEvaluasi,

Elex Media Komputinda, Jakarta.

Edy Topo Ashari dan Desi, 2001.Membangun pemerintah yang baik, (Bahan Ajar Diklatpim Tingkat III),LAN RI, Jakarta.

Haris, Andi, 2006. Cegah Korupsi, Bangun Good Governance (Artikel) Harian Fajar, No. 60 Tahun XXV Hal 4.

Hasibuan, Malayu SP, 2001, Manajemen Sumber Daya Manusia. Bumi Aksara, Jakarta. Ismail Mohammad dkk, 2004, Konsep dan Pengukuran Akuntabilitas,Universitas Trisakti, Jakarta.

Lili Rasjidi dan Ira Rasjidi, 2001, Dasar-Dasar Filsafat dan Teori Hukum, Citra Aditya Bakti, Bandung.

Mustopadidja, 1999. Format Bernegara Menuju Masyarakat Madani, LAN RI, Jakarta. Modul Sistem Akuntabilitas Kinerja Instansi Pemerintah Edisi Kedua, 2004, LAN RI, Jakarta. 
Rewansyah, Asmawi. 2010. Reformasi Birokrasi Dalam Rangka Good Governance. RizkyGrafis: Jakarta.

Rivai, Veithzal, 2004, Manajemen Sumber Daya Manusia Untuk Perusahaan, PT. Raja Grafindo Persada, Jakarta.

Riduan, 2008.Metode dan Teknik Menyusun Tesis, Penerbit, Alfabeta, Bandung.

Rivai, veithazal, 2005. Manajemen Sumber Daya Manusia untuk Perusahaan dariTeori ke Praktek, Edisi Kesatu, Penerbit PT Raja Grafindo Persada, Jakarta.

Undang-Undang Republik Indonesia Nomor 2 tahun 2002 tentang Kepolisian Negara Republik Indonesia, Jakarta.

Undang-Undang Republik Indonesia Nomor 22 tahun 2009, tentang Lalu Lintas Angkutan Jalan, Jakarta.

Undang-undang Nomor 28 Tahun 2009 tentang Pelayanan Publik.

Undang-undang Nomor 28 Tahun 1998 tentang Penyelenggaraan Negara yang Bersih dan Bebas KKN, Jakarta.

Perkap Kapolri Nomor 8 tahun 2009, tentang Implementasi Prinsip dan Standar Hak Asasi Manusia dalam Penyelenggaraan Tugas Kepolisian Negara Republik Indonesia, Jakarta.

Peraturan Menteri Dalam Negeri Nomor 6 Tahun 2007 tentang Petunjuk Teknis Penyusunan dan Penetapan Standar Pelayanan Minimal. 